\title{
The Role of Sports on the Development of Tribes Unity: Afghan Society, Kabul, Afghanistan
}

\author{
Hizbullah Bahir \\ Teaching Assistant \\ Physical Education Department \\ Education Faculty, Kandahar University \\ Kandahar, Afghanistan \\ E-mail: bahir.hizbullah@hotmail.com
}

Received: September 08, 2020

doi: I0.4628I/aijssr.v5i3.794
Accepted: September 28, 2020

Online Published: October 09, 2020

URL: https://doi.org/I0.46281/aijssr.v5i3.794

\begin{abstract}
Sports play a major role in the life of humans as well as it has social and physical benefits for the humans' body. The purpose of this research was to investigate the role of sports, relationships between nation and Afghan community, and its impacts on the development of Afghan people life. This study employed mixed research approach, and the data were collected from seventynine respondents through questionnaire and interview. All participants were elected through random sampling method, and the data was analyzed through IBM 24 version of (SPSS). Likewise, the findings of this research showed that sports play an essential role in Afghan community as well as it is inseparable part in their life. Moreover, men and women are very interested in participating sports. Furthermore, the study revealed that participation in sports and physical activities play a unique role on the development of Afghan community and tribes.
\end{abstract}

Keywords: Sports, Development, National Unity, Effects, Afghan Society.

\section{Introduction}

Sports is any activity that implements physical effort or skills competitively under a set of rules that is not based on aesthetics. As well as, sports serve as a vehicle for the psychological, physical, cognitive and social development for those who do it. In addition, it is an activity which commands a degree of primary or secondary involvement unmatched by other institutionalized settings. Moreover, sports offer an opportunity for research on highly crystallized forms of social structure not found in other systems or situations (Luschen, 1990). At the same time, it is a product of social reality (Eitzen \& Frey, I99I). Furthermore, sports serve as a catalyst and bring people together and influence social relations as teammates work toward a common goal.

Likewise, sports and physical activities reduce stress, improves the quality of sleep and prevents diseases. Also, it is helpful for the therapy of several chronic diseases. In addition, sports refer to a conscious and organized social activity that uses physical exercises as the basic means to enhance people's body, promote the overall development of people, enrich social and cultural life and promote spiritual civilization. It is a part of every culture in a society, and the development of sports is restricted by the politics and economy of a certain community (Bahir, 2017). Additionally, all forms of physical activity through casual and organized participation which express or improve physical fitness and mental well-being, form social relationships or obtain results in competition at all levels is known as sports (Europe \& Ministers, 200I).

Similarly, sports are also beginning to emerge as one of the powerful arms of globalization, and it is trying to alleviate tensions between wounded nations. Also, it can make people around the world to get know each other and push the process of globalization into the path of peace. This case has two major dimensions; in the atmosphere of world sports competitions, you know the countries that you did not even noticed have existed, such as their people, culture, flag, languages and clothes. The second issue is in sports, wars and enmities become controlled and symbolic because it makes all people of the world as a part of the body. Additionally, there are limited studies carried out regarding the role of sports on the development of tribes' unity in Kabul, Afghanistan. As a result, this research tries to fill this gap in this existence context through conducting this study. Lastly, this research would help with Physical Education Directorate of Kabul, Afghanistan and other stakeholders. 


\subsection{Research Objectives}

- To investigate the role of sports on the development of national unity, Kabul, Afghanistan.

- To assess the relationship of nation and sports development on Afghan society, Kabul, Afghanistan.

- To explore the effects of sports on Afghan people life at Kabul, Afghanistan.

\section{I.3 Research Questions}

- What is the role of sports on the development of national unity, Kabul, Afghanistan?

- What is the relationship of nation and sports development on Afghan society, Kabul, Afghanistan?

- What are the effects of sports on Afghan people life at Kabul, Afghanistan?

\section{Literature Review}

Sports teams are subject to consistency due to the large number of members and need for members to adapt. Consistency is the result of changes in behavior or beliefs caused by group pressure (Myers \& Twenge, 2018). Moreover, a work team can build a common image of how to best solve existing challenges through collective mental imagery, thereby it potentially improves its performance (Manz \& Neck, 1995). Sports teams also have a high ability to create cohesion and it is a process that can achieve its goals through a united team (Carron, Bray \& Eys, 2002). There are two types of coordination in community job coordination and social unity that can be achieved when joined teams are made, and the members of teams work together in order to achieve common goals, and interacts with each other (Richardson, 2013). In addition, social cohesion determines the degree to which each member of the team likes each other and interacts accordingly (Richardson, 2013). Each of these cohesive forces can work together to form sports teams and help them succeed. Sports teams often aim to work together. However, most sports teams are likely to face integration in one aspect or another. Consistency is usually looking for possible negative effects, but without consistency, there can be no team.

On the other hand, cohesion is often seen as a more positive outlook for the teams to achieve because high cohesion within the team can make it difficult to maintain and may lead to collective thinking, thereby reducing innovation (Wise, 20I 4). At community level, sports have been promoted as a mechanism that promotes social unity, encourages strong community connections, reduces crime rates, and provides active mentors (Chamberlain, 2013; Dacombe, 2013). These positive effects are important to community. Sport may create relationships and social cohesion in religion, race and economics, but there is a little clear evidence to support this claim (Beutler, 2008). Recently, research on sports for development and peace advocates how to use sports as a tool to intervene in a complex and deeply divided society, and to promote mutual understanding and conflict resolution between different classes at the grassroots level (Darnell, Whitley \& Massey, 20I6; Sugden, 20I5). Sports-based interventions are increasingly becoming a tool for interacting with young people (Lindsey, 20I3; Stride \& Fitzgerald, 20I7), because they are a way to alleviate the distorted relationship between young people and agencies. They provide opportunities to socialize, interact and collaborate behavior, promote cultural learning, trust and build networks (Haudenhuyse, Theeboom $\&$ Nols, 2013). If promoted in the right way, positive experiences will dominate and multiple inclusive social identity can be achieved (Schulenkorf, 2010).

Moreover, sports can exclude individuals and groups and further divide communities. Sports is certainly not a social remedy. According to Perkins (2000) that ethnic minority youth, especially those living in non-rich communities, do not participate equally in organized sports. This means that they may become isolated from the wider network of countries and communities and lose support for access to social and economic resources. In addition, it cannot play a role to minimize inequality as well it cannot independently solve the disadvantages of society (Spaaij, 2013). Furthermore, sports form part of a broader set of process designed to address the causes of inequality. Dealing with complex issues in a liberating manner has obvious value, but this must be supported by broader support from other organizations, policy makers and so on. The study of sports as a social phenomenon is rarely defined as an activity that provides spiritual benefits to those who do it. Sports as a social event is given low priority, but in fact people who are professionals in spots and do it have a comfortable life than other people in a community (Carrington \& Mcdonald, 2008; Long, Fletcher \& Watson, 2017).

Furthermore, sports promote unity, relations and progress among politicians in every society (Bethell-Bennett, 20I4). There are many effects of football game on people and society, which can lead to a new way of thinking about the natural relationship of contrasts between structure and administration in society (Dixon, 20I I). However, the tolerance can represent a new way of thinking about the natural relationship of contradictions between structure and agency in society. In a structured theory, agency and structure are not mutually dominant. Social systems are copied from social practices that existed in time and space because they are followed by most members of society (Sadan I997; Dixon, 201 I). 


\section{Research Methodology}

This current study investigated the role of sports on the development of national unity, relationships of nation and sports and its impacts on Afghan people life in Kabul, Afghanistan. Likewise, this research used mixed method and the data were collected from participants through questionnaire and interview as well as they were selected through a random sampling approach. Moreover, seventy-nine respondents were selected from National Olympic Committee and Physical Education Directorate of Kabul, Afghanistan. In addition, the items of the questionnaire were analyzed by using IBM 24 version of Statistical Package for Social Science (SPSS).

\section{Discussion}

The findings of this study show that sports play an essential role among Afghan community. Moreover, sports in Afghanistan also have economic, social, health and cultural effects on community, especially it has deep effects on the peace and mutual tolerance. According to Dixan (20II) that there are many effects of football on people and society, which can lead them to a new way of thinking about the natural relationship of contrasts between structure and administration in society. The study further showed that sports brings positive changes in social relationship. Similarly, the finding of this research reveals that sports is inseparable part in the life of Afghans. The finding of this study can be supported by Long, Fletcher and Watson (2017) that sports is a social phenomenon which has spiritual benefits to sportsmen. Furthermore, sports as a social event which given low priority, but it has many advantages to health of humans.

In addition, the findings of this study showed that men and women have zeal to participate in sports as well as play with the players of other countries on international matches. Therefore, many Afghan men and women are no busy on different sports and want to build strong and develop teams on the national and international levels. Also, they try to find way in order to be played on the international level with other teams. This finding can be somehow supported by Chamberlain (2013) \& Dacombe (2013) that at community level, sports have been promoted as a mechanism that promotes social cohesion, encourages strong community connections, reduces crime rates, and provides active mentors. Moreover, participation of many women in the field of sports has attracted the attention of other countries than looking to the past years. Additionally, the findings of this research show more that participation on sports and physical activities play unique role between Afghans and in the development of Afghan community and tribes.

\section{Conclusion}

The research studied the role of sports, relationships of nation and the progress of sports on Afghan society, Kabul, Afghanistan. This study carried out in Kabul province, Afghanistan. Majority respondents were young people both men and women and they were all select through random sampling method. Additionally, sports play an essential role after war in Afghanistan and most people spent their free time on various sports and physical activities. In addition, sports are inseparable part in the life Afghans. This study further revealed that men and women in Afghanistan have enthusiasm to participate as well play with other countries on international matches. Furthermore, the findings disclosed that participation on sports and physical activities play a unique role among Afghans and on the development of Afghan community and tribes.

\section{References}

Bahir, H. (2017). Fundamentals of Physical Education, Waygal Publications. p2.

Bethell-Bennett, I. A. (20I4). Amanda Sives. 20I0. Elections, Violence and the Democratic Process in Jamaica I944-2007 Deborah A. Thomas. 20I I. Exceptional Violence: Embodied Citizenship in Transnational Jamaica.

Beutler, I. (2008). Sport serving development and peace: Achieving the goals of the United Nations through sport. Sport in society, $I I(4), 359-369$.

Carrington, B., \& Mcdonald, I. (2008). The Politics of 'Race'and Sports Policy in the United Kingdom'. Sport and Society: A Student Introduction, 2, 230-254.

Carron, A. V., Bray, S. R., \& Eys, M. A. (2002). Team cohesion and team success in sport. Journal of sports sciences, 20(2), II9-I26.

Chamberlain, J. M. (2013). Sports-based intervention and the problem of youth offending: a diverse enough tool for a diverse society? Sport in Society, I6(I0), I279-I292.

Dacombe, R. (20I3). Sports clubs and civic inclusion: rethinking the poverty of association. Sport in society, I6(I0), I263$\mathrm{I} 278$.

Darnell, S. C., Whitley, M. A., \& Massey, W. V. (2016). Changing methods and methods of change: Reflections on qualitative research in sport for development and peace. Qualitative Research in Sport, Exercise and Health, 8(5), 57 I-577.

Dixon, K. (201I). A 'third way'for football fandom research: Anthony Giddens and structuration theory. Soccer \& Society, I2(2), 279-298. 
Eitzen, D. S., \& Frey, J. H. (I99I). Sport and society. Annual Review of Sociology, I7( I), 503-522.

Europe, C., \& Ministers, C. (200I). European Sports Charter.

Haudenhuyse, R., Theeboom, M., \& Nols, Z. (2013). Sports-based interventions for socially vulnerable youth: Towards welldefined interventions with easy-to-follow outcomes. International Review for the Sociology of Sport, 48(4), 47 I-484.

Lindsey, I. (2013). Community collaboration in development work with young people: Perspectives from Zambian communities. Development in practice, 23(4), 48I-495.

Long, J., Fletcher, T., \& Watson, B. (Eds.). (2017). Sport, leisure and social justice. Taylor \& Francis.

Luschen, G. (1990). On theory of science for the sociology of sport: new structuralism, action, intention and practical meaning. International review for the sociology of sport, 25(I), 49-63.

Manz, C. C., \& Neck, C. P. (I995). Teamthink: beyond the groupthink syndrome in self-managing work teams. Journal of Managerial Psychology, IO(I), 7-I5.

Myers, D. G., \& Twenge, J. M. (20I8). Exploring social psychology (8th ed.). New York, NY: McGraw-Hill Education.

Perkins, S. (2000). Exploring future relationships between football clubs and local government. Soccer \& Society, I(I), I02II3.

Richardson, A. (2013). Group cohesion. Retrieved December 03, 2017, from http://www.idfpa.net/sports-psychology--group-cohesion

Sadan, E. (1997). Developing a Theory of Empowerment, Empowerment and Community Planning. Theory and Practice of People-Focused Social Solutions, Hameuchad Publishers, Tel Aviv.

Schulenkorf, N. (2010). Bridging the divide: The role of sport events in contributing to social development between disparate communities. European Journal of Tourism Research, 3(2), 127.

Spaaij, R. (2013). Cultural diversity in community sport: An ethnographic inquiry of Somali Australians' experiences. Sport Management Review, I6( I), 29-40.

Stride, A., \& Fitzgerald, H. (2017). Working towards social justice through participatory research with young people in sport and leisure. In Sport, Leisure and Social Justice (pp. 98-I I0). Routledge.

Sugden, J. (2015). Assessing the sociology of sport: On the capacities and limits of using sport to promote social change. International review for the sociology of sport, 50(4-5), 606-6I I.

Wise, S. (2014). Can a team have too much cohesion? The dark side to network density. European Management Journal, 32(5), 703-7II.

\section{Copyrights}

Copyright for this article is retained by the author(s), with first publication rights granted to the journal. This is an open-access article distributed under the terms and conditions of the Creative Commons Attribution license (http://creativecommons.org/licenses/by/4.0/). 